\title{
The prognostic significance of overexpression of the decoy receptor for Fas ligand (DcR3) in patients with gastric carcinomas
}

\author{
Yasushi Takahama, Yukishige Yamada, Koji Emoto, Heisuke Fujimoto, Tomoyoshi Takayama, \\ Masatoh Ueno, Hideki Uchida, Shuya Hirao, Takashi Mizuno, and Yoshiyuki Nakajima \\ First Department of Surgery, Nara Medical University, Kashihara, Nara 634-8522, Japan
}

\begin{abstract}
Background. The FasL-Fas system has an important role in mediating immune-cytotoxic killing of cells such as virusinfected or tumor cells. It was recently reported that there is a soluble decoy receptor (DcR3), which binds to FasL and inhibits FasL-induced apoptosis, and certain tumors may escape FasL-dependent immune-cytotoxic attack by expressing a decoy receptor that blocks FasL. We evaluated whether DcR3 has clinical relevance in actual human gastric cancers. Methods. The expression of DcR3 was investigated by Northern blot analysis in a series of 84 primary gastric carcinomas and compared with clinicopathological features and prognosis. The DcR3 expression level was analyzed and quantified densitometrically. The location of $D c R 3$ mRNA in gastric carcinoma tissue was detected by in situ hybridization.

Results. The frequency of DcR3 overexpression was $26 \%$ (22 of 84 surgical specimens). The DcR3 expression level was significantly associated with lymph node metastasis and pathological stage, but did not correlate with tumor size, metastatic status, or histological type. In situ hybridization demonstrated that $D c R 3$ mRNA was expressed in tumor cells. When the patients were followed up for 63 months, DcR3 overexpression was found to be associated with a significantly shortened duration of overall survival compared with findings in patients having normal DcR3 expression.

Conclusion. The DcR3 decoy receptor for FasL may be involved in the progression of gastric cancer. Further evaluation of these possible roles of DcR3 and the regulation of DcR3 expression in malignant cells will be critically important for the development of new strategies for controlling the growth of malignant cells that escape host immune surveillance.
\end{abstract}

Key words Decoy receptor for Fas ligand - Gastric cancer . Northern blot - Clinicopathological features - Prognosis . Apoptosis

Offprint requests to: Y. Takahama

Received: July 19, 2001 / Accepted: December 21, 2001

\section{Introduction}

The immune escape of tumor cells and successful tumor outgrowth may be due to the inability of the immune system to react to the tumor. Despite the expression of tumor rejection antigens, such as MAGE 1-3 [1-3], and the presence of tumor-specific cytotoxic T cells [2], the immune system fails to contain gastric carcinoma. The evidence suggests that a poor local immune response contributes to the potential for lymph nodal metastatic spread of gastric tumors [3]. This mechanism by which gastric cancers overcome antitumor immunological responses is poorly understood.

Fas ligand (FasL) is produced by activated $\mathrm{T}$ cells and natural killer (NK) cells, and it induces apoptosis in target cells through the death receptor Fas/Apo1/CD95 [4-9]. One important role of FasL-Fas systems is to mediate immune-cytotoxic killing of cells that are harmful to the organism, such as virus-infected or tumor cells $[10,11]$. The involvement of FasL and Fas as a possible mechanism whereby tumors escape the immune system has recently been proposed. As one of the mechanisms, a "Fas counterattack" model of tumor immune escape was proposed, in which a cancer cell, by expressing FasL, may remove Fas-sensitive immune effector cells by apoptosis. Evidence for this mechanism of tumor immune privilege by "Fas counterattack" has since been provided for several cancers; gastric carcinoma [12], melanoma [13], hepatocellular carcinoma [14], lung cancer [15], astrocytoma [16], colon cancer [17], and liver metastasis of colon adenocarcinoma [18] have been shown to express FasL. On the other hand, some reports suggest that other immune escape mechanisms allowed the eventual establishment of tumors without the Fas system [19-21].

As to the mechanism by which the FasL function is controlled, it was recently reported that there is a soluble decoy receptor (DcR3) [22,23], which binds to FasL and inhibits FasL-induced apoptosis. DcR3, a 
member of the tumor necrosis factor receptor (TNFR) superfamily, shares sequence identity in particular with osteoprotegerin (31\%) [24] and TNFR 2 (29\%), and has relatively less homology with Fas (17\%). The DcR3 gene was amplified in about half of primary lung and colon cancers [22], and was overexpressed in human adenocarcinomas of gastrointestinal tract regions [25], suggesting that certain tumors may escape FasLdependent immune-cytotoxic attack by expressing a decoy receptor which blocks FasL. DcR3 is expressed in the fetal brain, lung, and liver, and in the adult spleen, lung, and colon, and maps to chromosome position 20q13, which is the amplicon in various cancers [26-37].

To evaluate whether DcR3 has clinical relevance in actual human gastric cancers, we investigated the expression of the $D c R 3$ gene by Northern blot analysis in primary gastric carcinomas, compared with the clinicopathological features and prognosis.

\section{Patients and methods}

\section{Patients and tissue samples}

Tissue specimens taken from 84 gastric cancer patients who underwent operations at the First Department of Surgery, Nara Medical University, from January 1991 to December 1997, were used. Cancerous tissues and the respective noncancerous tissues adjacent to tumor areas were frozen immediately after surgical removal, in liquid nitrogen, and stored at $-80^{\circ} \mathrm{C}$ for subsequent Northern blot analysis. The histological types, numbers, and pathological stages of the primary gastric cancers, as well as the patients' sex, are shown in Table 1 . The pathological stage was classified according to the tumornode-metastasis classification of gastric carcinoma of the Union Internationale Contre Cancer. The Lauren classification was used for histological type .

\section{Preparation of cDNA probes}

A human DcR3 cDNA sequence was obtained by reverse transcription-polymerase chain reaction (RTPCR) amplification and used as a probe. Briefly, human spleen polyA RNA (Clontech, Palo Alto, CA, USA) was reverse-transcribed to cDNA with an oligodeoxythymidylic acid primer and then poly-A selected. The resultant cDNA was subjected to PCR to amplify the human $D c R 3$ fragment. The first PCR primer sequences were: 5'-CTACTGCAACGTCCTCTGT-3' for the forward primer and 5'-TGGAGATGTCCTGG AAAGGCC-3' for the reverse primer. The nested PCR primers were: 5'-CTACTGCAACGTCCTCTGT-3' for the forward primer and 5'-ACAGGGTGTCATGGG AGGAA-3' for the reverse primer. The PCR conditions were: $10 \mathrm{~min}$ at $95^{\circ} \mathrm{C}$ for preheating; 30 cycles of $1 \mathrm{~min}$ of denaturation at $95^{\circ} \mathrm{C}, 1 \mathrm{~min}$ of annealing at $65^{\circ} \mathrm{C}, 40 \mathrm{~s}$ of extension at $72^{\circ} \mathrm{C}$; and 10 -min post-

Table 1. Correlation of $D c R 3$ expression with clinicopathological features

\begin{tabular}{|c|c|c|c|c|}
\hline & \multirow[b]{2}{*}{ No. of tumors } & \multicolumn{2}{|c|}{$D c R 3$} & \multirow[b]{2}{*}{$P$ value } \\
\hline & & Overexpressed & Normal & \\
\hline \multicolumn{5}{|l|}{ Age } \\
\hline$<60$ years & 36 & 9 & 27 & \multirow[t]{2}{*}{ NS } \\
\hline$>60$ years & 48 & 13 & 35 & \\
\hline \multicolumn{5}{|l|}{ Sex } \\
\hline Male & 65 & 20 & 45 & \multirow[t]{2}{*}{ NS } \\
\hline Female & 19 & 2 & 17 & \\
\hline \multicolumn{5}{|l|}{ Tumor status } \\
\hline 1 & 12 & 1 & 11 & \multirow[t]{2}{*}{ NS } \\
\hline $2-4$ & 72 & 21 & 51 & \\
\hline \multicolumn{5}{|l|}{ Nodal status } \\
\hline Negative & 27 & 3 & 24 & \multirow[t]{2}{*}{0.03} \\
\hline Positive & 54 & 19 & 38 & \\
\hline \multicolumn{5}{|c|}{ Metastatic status $(\mathrm{P}, \mathrm{H})$} \\
\hline Negative & 75 & 19 & 56 & \multirow[t]{2}{*}{ NS } \\
\hline Positive & 9 & 3 & 6 & \\
\hline \multicolumn{5}{|l|}{ Stage } \\
\hline 1 & 23 & 2 & 21 & \multirow[t]{2}{*}{0.02} \\
\hline $2-4$ & 61 & 20 & 41 & \\
\hline \multicolumn{5}{|l|}{ Histological type } \\
\hline Intestinal type & 45 & 10 & 25 & \multirow[t]{2}{*}{ NS } \\
\hline Diffuse type & 38 & 12 & 26 & \\
\hline
\end{tabular}

NS, Not significant $(P>0.05)$; , peritoneal metastasis; $\mathrm{H}$, liver metastasis 
extension at $72{ }^{\circ} \mathrm{C}$. A $1-\mu \mathrm{l}$ aliquot of the first PCR reaction mixture was used for the nested PCR under the same PCR conditions. The amplified segments were verified by electrophoresis in $1 \%$ agarose gels with ethidium bromide, and extracted with a QIAquick PCR Purification Kit (Qiagen, Hilden, Germany), and then cloned in TA cloning vector (pGEM-T Easy Vector Systems; Promega, Madison, WI, USA). The sequence analysis was performed with a DNA sequencer (model 377; Applied Biosystems, Newark, CT, USA).

\section{Northern blot analysis}

Total RNA was extracted from cancerous and noncancerous stomach tissues using an Isogen kit (Nippon Gene, Toyama, Japan). Twenty-microgram aliquots were electrophoresed in 1\% agarose-formaldehyde gels, transferred to nylon membranes (Hybond $\mathrm{N}$ plus; Amersham, Buckinghamshire, UK), and hybridized with $1 \times 10^{6} \mathrm{cpm} / \mathrm{ml}$ of a ${ }^{32} \mathrm{P}$-radiolabeled $D c R 3 \mathrm{cDNA}$ probe, prepared using a DNA Labeling Kit (d-CTP) (Pharmacia Biotech, Uppsala, Sweden), in Rapid-hyb buffer (Amersham) and $100 \mu \mathrm{g} / \mathrm{ml}$ salmon testis DNA at $65^{\circ} \mathrm{C}$ for $2 \mathrm{~h}$. Membranes were washed in $2 \times$ standard saline citrate (SSC) and $0.1 \%$ sodium dodecylsulfate (SDS) at room temperature for $15 \mathrm{~min}$ and twice in $0.2 \times$ SSC and $0.1 \%$ SDS at $65^{\circ} \mathrm{C}$ for $15 \mathrm{~min}$. The $D c R 3$ expression level was then analyzed and quantified densitometrically with a BAS 1000 image analyzer (Fuji Photo Film, Tokyo, Japan). Next, membranes were exposed to Scientific Imaging Film (Kodak; Rochester, NY, USA) with an intensifying screen overnight at $-80^{\circ} \mathrm{C}$. After the exposure, the Northern blots were reprobed with a glyceraldehyde 3-phosphate dehydrogenase (GAPDH) cDNA probe to confirm that similar amounts of RNA were loaded and transferred from each sample. Within each sample, the density of the DcR3 mRNA band was determined by comparing the densities of the GAPDH bands. We categorized $D c R 3$ overexpression in cancerous tissues when the density was more than two fold enhanced compared with the values derived from the respective noncancerous samples.

\section{Preparation of riboprobes}

Digoxygenin-labeled sense or antisense riboprobes were synthesized by T3 or T7 RNA polymerase from cDNA plasmids containing entire coding sequences of human $D c R 3$ cDNA, in the presence of digoxygenindUTP (Boehringer-Mannheim, Mannheim, Germany).

\section{In situ hybridization}

In situ hybridization experiments, using fresh frozen tissue sections and digoxygenin-labeled riboprobes, were carried out. Gastric tissues were fixed with 4\% paraformaldehyde in phosphate-buffered saline (PBS) at $4{ }^{\circ} \mathrm{C}$ for $12 \mathrm{~h}$, then dehydrated in $30 \%$ sucrose in PBS at $4{ }^{\circ} \mathrm{C}$ for $4 \mathrm{~h}$, with gentle agitation, and then embedded in OCT and sectioned at a thickness of $10 \mu \mathrm{m}$. The sections were immediately dried at $45^{\circ} \mathrm{C}$ for $3 \mathrm{~h}$. Before hybridization, the slides were soaked in $0.2 \mathrm{~N} \mathrm{HCl}$ for $20 \mathrm{~min}$ to inactivate endogenous alkaline phosphatase, rinsed with deionized water, treated with proteinase $\mathrm{K}$ for $10 \mathrm{~min}$ at $37^{\circ} \mathrm{C}$, hydrated with ethanol, and then air dried. An appropriate amount of the probe in $50 \mu \mathrm{l}$ of hybridization buffer, consisting of $300 \mathrm{mM} \mathrm{NaCl}, 30 \mathrm{mM}$ sodium citrate, $50 \% \mathrm{v} / \mathrm{v}$ deionized formamide, $1 \% \mathrm{w} / \mathrm{v}$ SDS, $50 \mu \mathrm{g} / \mathrm{ml}$ heparin, and $50 \mu \mathrm{g} / \mathrm{ml}$ yeast RNA, was applied to each slide, and hybridization was carried out at $65^{\circ} \mathrm{C}$ for $12 \mathrm{~h}$. After hybridization, the slides were washed with $300 \mathrm{mM} \mathrm{NaCl}$-sodium citrate and $50 \%$ deionized formamide at $52{ }^{\circ} \mathrm{C}$ for $1 \mathrm{~h}$. Detection was carried out with an anti-digoxygenin antibody conjugated with alkaline phosphatase. Colorimetric reaction with nitroblue tetrazolium and 5-bromo-4-chloro-3indolyl-1-phosphate was carried out at room temperature for $48 \mathrm{~h}$. As the re-ference, methyl green staining was performed in serial sections.

\section{Statistical analyses}

$D c R 3$ expression in relation to pathological stage, histological type, and cancer cell differentiation was analyzed for significance, using the $\chi^{2}$ test. Overall survival periods were calculated by the Kaplan-Meier method, and the data were evaluated with the log-rank test. Multivariate analysis was performed using the Cox proportional hazards regression model, with StatView statistical software (Abacus Concepts, Berkeley, CA, USA).

\section{Results}

\section{Cloning of DcR3 $c D N A$}

Human $D c R 3$ cDNA was obtained by RT-PCR amplification. Human spleen polyA RNA was reverse transcribed to cDNAs, then the cDNAs were subjected to PCR to amplify the human $D c R 3$ cDNA fragment. A $1-\mu l$ aliquot of the first PCR reaction mixture was used for the nested PCR under the same PCR conditions. We obtained a 313-bp cDNA segment and confirmed the cDNA segment to be a $D c R 3$ cDNA by sequence analysis. 
DcR3 overexpression was associated with lymph node metastasis and pathological stage

In 84 patients recently operated for gastric cancer, paired samples of tumor and noncancerous stomach tissue were subjected to Northern blot analysis, using the cDNA probe for $D c R 3$. The patient distribution is listed in Table 1. DcR3 expression was detected in both tumor and noncancerous stomach tissue. Representative results of the Northern blot analysis are shown in Fig. 1a. In all instances, cancerous tissue was compared with the respective noncancerous tissues adjacent to the tumor areas in the same patient. This comparison is important, because, although $D c R 3$ mRNA was found to be expressed in all normal stomach tissues examined, the absolute level of DcR3 expression varies among individuals. The relative level of $D c R 3$ mRNA expression in the 84 paired samples (noncancerous and cancerous tissues) was quantified by densitometric scanning of Northern blots and normalized to the signal obtained by hybridizing to GAPDH mRNA (Fig. 1b). DcR3 mRNA was overexpressed in $22(26 \%)$ primary gastric carcinomas compared with each noncancerous tissue. The expression of $D c R 3$ was analyzed in comparison with the clinicopathological features. The following factors were considered: sex, age, tumor status, lymph node involvement, systemic metastasis, histological type, and stage. As shown in Table 1, there were no significant differences in sex, age, tumor status, systemic metastasis, and histological type between the $D c R 3$ expression levels. However, $D c R 3$ expression in cancerous tissue was significantly increased in lymph node metastasispositive patients $(35 \%)$ in comparison with lymph node metastasis-negative patients $(11 \% ; P=0.03)$. With respect to clinical stage, $D c R 3$ expression status also had a significant association. Specifically, $8.7 \%$ of stage 1 tumors and $32.8 \%$ stage $2-4$ tumors had $D c R 3$ overexpression $(P=0.02)$. Thus, $D c R 3$ overexpression in cancerous tissue was significantly associated with lymph node metastasis and pathological stage, but did not correlate with any other factors at a statistically significant level. The localization of $D c R 3$ in gastric carcinoma tissue was confirmed by in situ hybridization, using a $D c R 3$ antisense RNA probe. $D c R 3$ expression was seen in tumor cells (Fig. 2a), whereas $D c R 3$ expression was very weak or undetectable in stromal cells and noncancerous tissue (Fig. 2b). In contrast, the sense RNA probe did not show any signal (Fig. 2c).

\section{Prognostic significance of DcR3 overexpression for survival}

The prognostic significance of $D c R 3$ expression for patient survival was evaluated by univariate analysis (logrank test). In the entire group of gastric cancer patients,
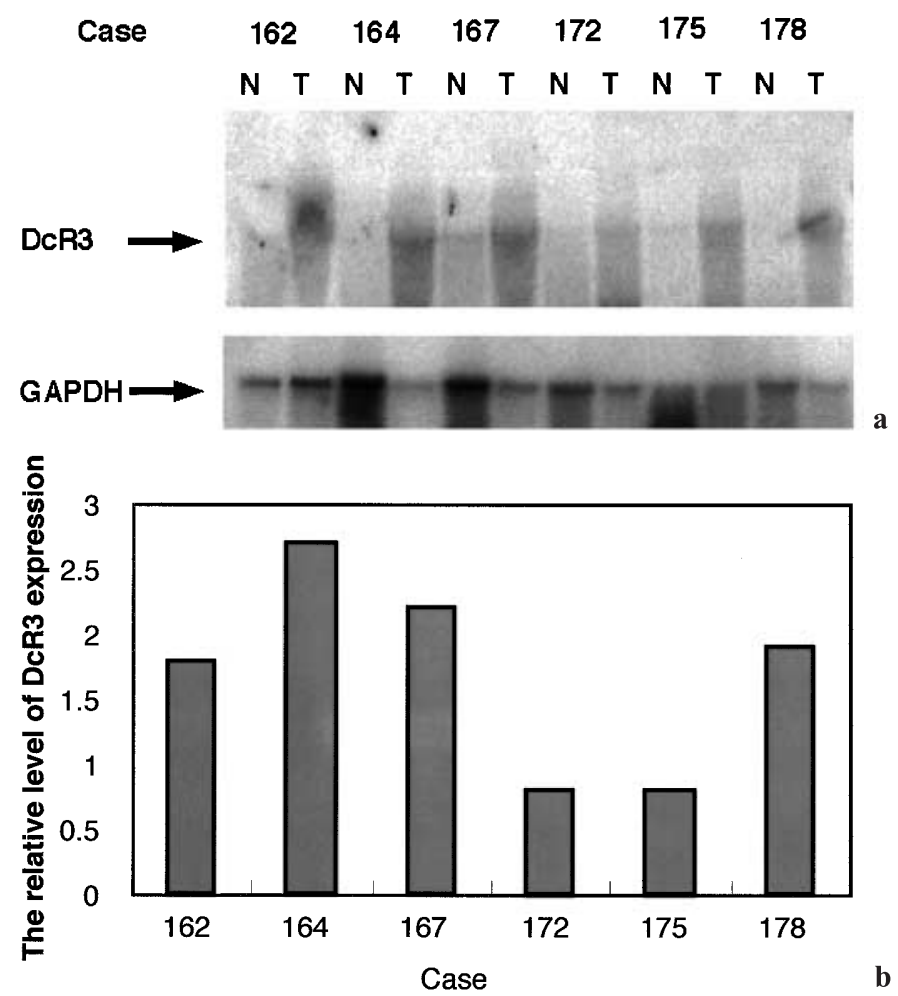

Fig. 1. a Northern blot analysis for $D c R 3$ mRNA in representative gastric cancer cases. Twenty micrograms of total RNA extracted from cancerous and noncancerous stomach tissues was electrophoresed in 1\% agarose-formaldehyde gels, transferred to a nylon membrane, and hybridized with a ${ }^{32}$ P-radiolabeled $D c R 3$ cDNA probe. The densities of each band were measured using a BAS 1000 image analyzer, and the density of the $D c R 3$ mRNA band was determined by comparing the densities of GAPDH bands. DcR3 overexpression was considered to be shown in cancerous tissues when the density was more than twofold enhanced compared with values derived from the respective non-cancerous samples. b mRNA overexpression in cancerous tissue is evident for some tumors, as compared with noncancerous stomach tissue. Numbers, Patient numbers; GAPDH, glyceraldehyde 3-phosphate dehydrogenase; $N$, Noncancerous tissue; $T$, tumor tissue

when followed up for 63 months, $D c R 3$ overexpression in cancerous tissue was found to be associated with a significantly shortened duration of overall survival compared with that in patients whose cancerous tissue expressed a normal level of $D c R 3$ (Fig. 3) $(P=0.016)$. Tumor status, lymph vessel invasion, and lymph node involvement were also factors associated with poor survival.

Multivariate analysis was carried out to further evaluate whether $D c R 3$ would serve as an independent factor to predict patient outcome. As shown in Table 2, tumor status and lymph node involvement, but not $D c R 3$ overexpression, were independent prognostic factors for survival. 

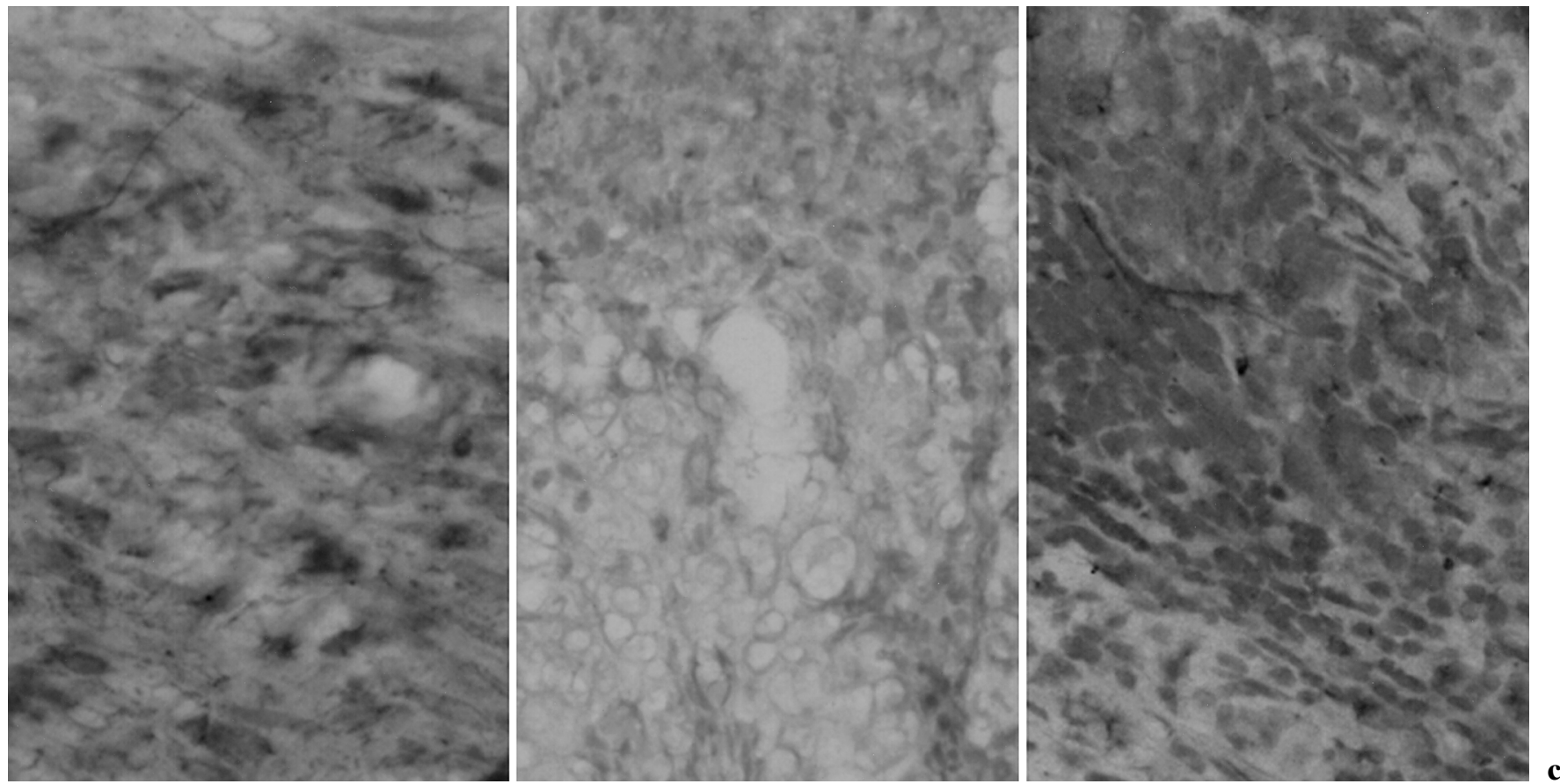

Fig. 2. a In situ hybridization, using the DIG Nuclear Acid Detection Kit, demonstrated that $D c R 3$ mRNA was expressed in tumor cells. b $D c R 3$ expression was very weak in noncancerous tissue. c Negative control, using a sense $D c R 3$ mRNA probe, is shown

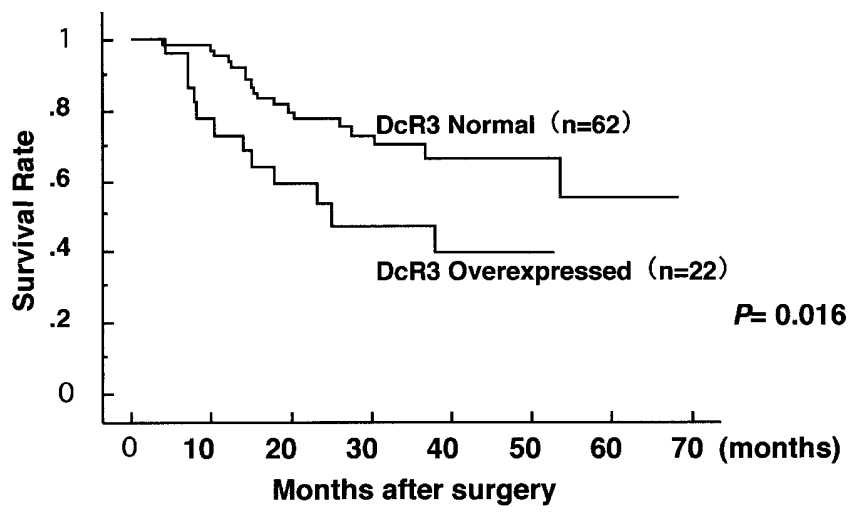

Fig. 3. Effect of $D c R 3$ on survival, according to level of expression. Kaplan-Meier survival curves are shown, with patients divided into groups based on the level of $D c R 3$ expression. In the entire group of gastric cancer patients, when followed up for 63 months, DcR3 overexpression in cancerous tissue was found to be associated with a significantly shortened duration of overall survival compared with that in patients whose cancerous tissue expressed a normal level of $D c R 3(P=0.016)$

\section{Discussion}

FasL is a member of the tumor necrosis factor family [49] and mediates apoptosis in many cell types, including both transformed and nontransformed cells $[4,5,10,11]$.
Table 2. Multivariate Cox proportional hazard analysis

\begin{tabular}{llrc}
\hline Prognostic factors & $\begin{array}{c}\text { Hazards } \\
\text { ratio }\end{array}$ & $95 \% \mathrm{CI}^{\mathrm{a}}$ & $P$ value \\
\hline Sex (female or male) & 0.96 & $0.33-2.83$ & 0.95 \\
Age ( $\leq 60$ or $>60$ years) & 1.46 & $0.7-3.05$ & 0.31 \\
Tumor status (T1 or T2-4) & 0.405 & $0.47-3.48$ & 0.41 \\
$\begin{array}{c}\text { Nodal status } \\
\quad(\text { negative or positive) }\end{array}$ & 0.065 & $0.01-0.39$ & 0.002 \\
$\begin{array}{c}\text { Metastatic status } \\
\quad \text { (negative or positive) }\end{array}$ & 0.27 & $0.10-0.75$ & 0.012 \\
DcR3 overexpression & 1.536 & $0.69-3.4$ & 0.29 \\
\hline${ }^{a}$ CI, Confidence interval & & &
\end{tabular}

FasL has been shown to play a crucial role in lymphocyte cytotoxicity [38-40] and is also important in mediating autocrine suicide in activated $\mathrm{T}$ lymphocytes [41-44]. The involvement of FasL and Fas as a possible mechanism whereby tumors escape the immune system has recently been proposed. A "Fas counterattack" model of tumor immune escape was proposed, in which a cancer cell, by expressing FasL, may remove Fassensitive immune effector cells by apoptosis. Evidence for this mechanism of tumor immune privilege by "Fas counterattack" has since been provided for several cancers; gastric carcinoma [12], melanoma [13], hepatocellular carcinoma [14], lung cancer [15], astrocytoma [16], 
colon cancer [17], and liver metastasis of colon adenocarcinoma [18] have been shown to express FasL. On the other hand, some reports do not support a role for FasL expression in the escape of tumors from immune destruction; overexpression of FasL does not confer immune privilege to a pancreatic beta tumor cell line [19]; human melanoma cell lines do not express FasL [20]; and the Fas system is not significantly involved in apoptosis in human hepatocellular carcinoma [21]. These reports indicate that there may be other mechanisms of tumor immune escape besides Fas counterattack. Tumor cells have been shown to prevent a T-cell immune response by various means, including downregulation of MHC class I molecules [45,46], lack of co-stimulative signals such as B7 [47,48], secretion of immunoinhibitory proteins such as transforming growth factor (TGF)- $\beta$ [49], loss of $\zeta$ signal transducing chains from tumor-infiltrating lymphocytes [50-52], and the interaction of neoplastic cells with the inhibitory CTLA-4 receptor [53].

The $D c R 3$ gene, a member of the TNFR superfamily, was recently reported to be a soluble decoy receptor, which binds to FasL and inhibits FasL-induced apoptosis. The $D c R 3$ gene was amplified in about half of primary lung and colon cancers [22] and was overexpressed in human adenocarcinomas of gastrointestinal tract regions [25], which suggested that certain tumors may escape FasL-dependent immune-cytotoxic attack by expressing a decoy receptor that blocks FasL. To evaluate whether DcR3 has clinical relevance in actual human gastric cancers, we investigated the expression of the $D c R 3$ gene in primary gastric carcinomas. In this report, we have shown that some stomach cancers overexpress $D c R 3$, an inhibitor of immunocyte apoptosis.

$D c R 3$ overexpression by gastric cancerous tissue was significantly associated with lymph node metastasis, but did not correlate with any other factors, such as tumor status and systemic metastasis. DcR3 overexpression in cancerous tissue was found to be associated with a significantly shortened duration of overall survival compared with that in patients whose cancerous tissue expressed normal levels of $D c R 3$, by univariate analysis, but $D c R 3$ overexpression was not an independent prognostic factor for survival by multivariate analysis. Tumor status, lymph vessel invasion, and lymph node involvement were the factors associated with poor survival. These results indicate that $D c R 3$ overexpression may be involved mainly in lymph vessel and node invasion of tumors, by inhibiting FasL-induced apoptosis through activated T cells and NK cells in patients with gastric carcinomas.

Cancerous tissue contains both cancer cells and normal stomach tissue, so it may be that the adjacent normal epithelial cells or stromal cells overexpress $D c R 3$.
The evidence shows that, in the analysis of $D c R 3$ expression in squamous cell carcinoma of the lung by in situ hybridization, $D c R 3$ mRNA was localized to the infiltrating malignant epithelium, but was essentially absent from adjacent stroma [22]. To detect the localization of $D c R 3$ mRNA in gastric carcinoma tissue, we performed in situ hybridization, using the DIG Nuclear Acid Detection Kit (Roche Molecular Biochemicals, Mannheim, Germany). DcR3 mRNA was expressed in tumor cells, but $D c R 3$ expression was very weak in stromal cells and noncancerous tissue.

The DcR3 gene maps to chromosome position 20q13 [22], which is the amplicon in various cancers; breast cancer [26-28], colorectal carcinoma [29,30], renal cell carcinoma [31], prostate cancer [32], uroepithelial cells [33], ovarian cancer [34], astrocytic tumor [35], chondrosarcomas [36], and gastric carcinoma [37]. These results suggest that there are essential genes on 20q13 which are concerned with the malignant potential of tumors, indicating that $D c R 3$ may be one of the candidate genes in the progression not only of gastric cancer but also of other organ carcinomas.

Our findings conclusively show, at the mRNA level, that some human gastric cancers overexpress $D c R 3$. Gastric cancer may therefore be added to the growing list of malignancies that appear to be immunologically prevalent through $D c R 3$ overexpression. The high prevalence of $D c R 3$ expression in the tumors suggests that this molecule may be critical to tumor immune privilege. It has not been evaluated whether or not DcR3 is identified in sera. If circulating forms of DcR3 are also increased in the blood in cancer patients, this could contribute to the generalized depression of cellular immunity seen in patients with neoplastic disease. In conclusion, the DcR3 decoy receptor for FasL may be involved in the progression of gastric cancer. Further evaluation of these possible roles of DcR3 and the regulation of DcR3 expression in malignant cells will be critically important for the development of new strategies for controlling the growth of malignant cells that escape host immune surveillance.

\section{References}

1. Inoue $\mathrm{H}$, Mori M, Honda M, Li J, Shibuta K, Mimori K, et al. The expression of tumor-rejection antigen "MAGE" genes in human gastric carcinoma. Gastroenterology 1995;109:1522-5.

2. Hoshino $\mathrm{T}$, Seki N, Kikuchi M, Kuramoto $\mathrm{T}$, Iwamoto $\mathrm{O}$, Kodama I, et al. HLA class I-restricted and tumor-specific CTL in tumor-infiltrating lymphocytes of patients with gastric cancer. Int J Cancer 1997;70: 631-8.

3. Maehara Y, Tomisaki S, Oda S, Kakeji Y, Tsujitani S, Ichiyoshi Y, et al. Lymph node metastasis and relation to tumor growth potential and local immune response in advanced gastric cancer. Int $\mathbf{J}$ Cancer 1997;74: 224-8.

4. Nagata S, Golstein P. The Fas death factor. Science 1995;267: $1449-56$. 
5. Itoh $\mathrm{N}$, Yonehara S, Ishii A, Yonehara M, Mizushima S, Sameshima M, et al. The polypeptide encoded by the cDNA for human cell surface antigen Fas can mediate apoptosis. Cell 1991;66:233-43.

6. Suda T, Takahashi T, Golstein P, Nagata S. Molecular cloning and expression of the Fas ligand, a novel member of the tumor necrosis factor family. Cell 1993;75:1169-78.

7. Lynch D, Ramsdell F, Alderson MR. Fas and FasL in the homeostatic regulation of immune responses. Immunol Today 1995;16: 569-74.

8. Nagata S, Suda S. Fas and Fas ligand: lpr and gld mutations. Immunol Today 1995;16:39-43.

9. Takahashi T, Tanaka M, Inazawa J, Abe T, Suda T, Nagata S. Human Fas ligand: gene structure, chromosomal location and species specificity. Int Immunol 1994;6:1567-74.

10. Nagata S. Apoptosis by death factor. Cell 1997;88:355-65.

11. Cleveland JL, Ihle JN. Contenders in FasL/TNF death signaling. Cell 1995;81:479-82.

12. Bennett MW, O'Connell JO, O'Sullivan GC, Roche D, Brady C, Kelly J, et al. Expression of Fas ligand by human gastric adenocarcinomas: potential mechanism of immune escape in stomach cancer. Gut 1999;44:156-62.

13. Hahne M, Rimoldi D, Schroter M. Melanoma cell expression of Fas (Apo-1/CD95) ligand: implications for tumor immune escape. Science 1996;274:1363-6.

14. Strand S, Hofmann WJ, Hug H, Muller M, Otto G, Strand D, et al. Lymphocyte apoptosis induced by CD95(Apo-1/Fas) ligandexpressing tumor cells: a mechanism of immune evasion? Nat Med 1996;2:1361-6.

15. Niehans GA, Brunner T, Frizelle SP, Liston JC, Salerno CT, Knapp DC, et al. Human lung carcinomas express Fas ligand. Cancer Res 1997;57:1007-12.

16. Saas P, Walker PR, Hahne M, Quiquerez AL, Schnuriger V, Perrin $\mathrm{G}$, et al. Fas ligand expression by astrocytoma in vivo: maintaining immune privilege in the brain? J Clin Invest 1997; 99:1173-8.

17. O'Connell J, O'Sullivan GC, Collins JK, Shanahan F. The Fas counterattack: Fas-mediated T cell killing by colon cancer cells expressing Fas ligand. J Exp Med 1996;184:1075-82.

18. Shiraki K, Tsuji N, Shioda T, Isselbacher KJ, Takahashi $\mathrm{H}$. Expression of Fas ligand in liver metastasis of human colonic adenocarcinomas. Proc Natl Acad Sci USA 1997;94:6420-5.

19. Okamoto S, Takamizawa S, Bishop PW, Wen J, Kimura K, Sandler A. Overexpression of Fas ligand does not confer immune privilege to a pancreatic beta tumor cell line (betaTC-3). J Surg Res 1999;84:77-81.

20. Chappell DB, Zak TZ, Rosenberg SA, Restifo NP. Human melanoma cells do not express Fas (Apo-1/CD95) ligand. Cancer Res 1999;59:59-62.

21. Kubo K, Matsuzaki Y, Okazaki M, Kato A, Kobayashi N, Okita K. The Fas system is not significantly involved in apoptosis in human hepatocellular carcinoma. Liver 1998;18:11723.

22. Pitti RM, Marsters SA, Lawrence MR, Kischkel PD, Dowd P, Huang A, et al. Genomic amplification of a decoy receptor for Fas ligand in lung and colon cancer. Nature 1998;396:699-703.

23. Yu KY, Kwon B, Ni J, Zhai Y, Ebner R, Kwon BS. A newly identified member of tumor necrosis factor receptor superfamily (TR6) suppresses LIGHT-mediated apoptosis. J Biol Chem 1999; 274:13733-6.

24. Simonet W, Lacey DL, Dunstan CR, Kelley M, Chang MS, Luthy R, et al. Ostoprogerin: a novel secreted protein involved in the regulation of bone density. Cell 1997;89:309-19.

25. Bai C, Connolly B, Metzker ML, Hilliard CA, Liu X, Sandig V, et al. Overexpression of M68/DcR3 in human gastrointestinal tract tumors independent of gene amplification and its location in a four-gene cluster. Proc Natl Acad Sci USA 2000;97:1230-5.

26. Tanner MM, Tirkkonen M, Kallioniemi A, Holli K, Collins C, Kowbel D, et al. Amplification of chromosomal region 20q13 in invasive breast cancer: prognostic implications. Clin Cancer Res 1995;1:1455-61.

27. Courjal F, Theillet C. Comparative genomic hybridization analysis of breast tumors with predetermined profiles of DNA amplification. Cancer Res 1997;57:4368-77.

28. Tanner MM, Tirkkonen M, Kallioniemi A, Isola J, Kuukasjarvi T, Collins $\mathrm{C}$, et al. Independent amplification and frequent coamplification of three nonsyntenic regions on the long arm of chromosome 20 in human breast cancer. Cancer Res 1996;56: 3441-5.

29. Korn WM, Yasutake T, Kuo WL, Warren RS, Collins C, Tomita $\mathrm{M}$, et al. Chromosome arm 20q gains and other genomic alterations in colorectal cancer metastatic to liver, as analyzed by comparative genomic hybridization and fluorescence in situ hybridization. Genes Chromosom. Cancer 1999;25:82-90.

30. De Angelis PM, Clausen OP, Schjolberg A, Stokke T. Chromosomal gains and losses in primary colorectal carcinomas detected by $\mathrm{CGH}$ and their associations with tumour DNA ploidy, genotypes and phenotypes. Br J Cancer 1999;80:526-35.

31. Medeiros LJ, Palmedo G, Krigman HR, Kovacs G, Beckwith JB. Oncocytoid renal cell carcinoma after neuroblastoma: a report of four cases of a distinct clinicopathologic entity. Am J Surg Pathol 1999:23:772-80.

32. Stubbs AP, Abel PD, Golding M, Bhangal G, Wang Q, Waxman $\mathrm{J}$, et al. Differentially expressed genes in hormone refractory prostate cancer: association with chromosomal regions involved with genetic aberrations. Am J Pathol 1999;154:1335-43.

33. Savelieva E, Belair CD, Newton MA, DeVries S, Gray JW, Waldman F, Reznikoff CA. 20q gain associates with immortalization: $20 \mathrm{q} 13.2$ amplification correlates with genome instability in human papillomavirus 16 E7 transformed human uroepithelial cells. Oncogene 1997;14:551-60.

34. Sonoda G, Palazzo J, du Manoir S, Godwin AK, Feder M, Yakushiji M, Testa JR. Comparative genomic hybridization detects frequent overrepresentation of chromosomal material from 3q26, 8q24, and 20q13 in human ovarian carcinomas. Genes Chromosom. Cancer 1997;20:320-8.

35. Nishizaki T, Ozaki S, Harada K, Ito H, Arai H, Beppu T, Sasaki $\mathrm{K}$. Investigation of genetic alterations associated with the grade of astrocytic tumor by comparative genomic hybridization. Genes Chromosom. Cancer 1998;21:340-6.

36. Larramendy ML, Tarkkanen M, Valle J, Kivioja AH, Ervasti H, Karaharju E, et al Gains, losses, and amplifications of DNA sequences evaluated by comparative genomic hybridization in chondrosarcomas. Am J Pathol 1997;150:685-91.

37. Sakakura C, Mori T, Sakabe T, Ariyama Y, Shinomiya T, Date K, et al. Gains, losses, and amplifications of genomic materials in primary gastric cancers analyzed by comparative genomic hybridization. Genes Chromosom. Cancer 1999;24:299-305.

38. Henkart PA. Lymphocyte-mediated cytotoxicity: two pathways and multiple effector molecules. Immunity 1994;1:343-6.

39. Berke G. The CTL's kiss of death. Cell 1995;81:9-12.

40. Doherty PC. Cell-mediated cytotoxicity. Cell 1995;84:607-12.

41. Singer GG, Abbas AK. The fas antigen is involved in peripheral but not thymic deletion of $\mathrm{T}$ lymphocytes in $\mathrm{T}$ cell receptor transgenic mice. Immunity 1994;1:365-71.

42. Alderson MR, Tough TW, Davis-Smith T, Braddy S, Falk K, Schooley KA, et al. Fas ligand mediates activation-induced cell death in human T lymphocytes. J Exp Med 1995;181:717.

43. Brunner T, Mogil SJ, LaFace D, Yoo NJ, Mahboubi A, Echeverri F, et al. Cell-autonomous Fas (CD95)/Fas-ligand interaction mediates activation-induced apoptosis in T-cell hybridomas. Nature 1995;373:441-4.

44. Dhein J, Walczak H, Baumler C, Debatin KM, Krammer PH. Autocrine T-cell suicide mediated by APO-1/. Nature 1995;373: 438-41.

45. Cordon-Cardo C, Fuks Z, Drobnjak M, Moreno C, Eisenbach L, Feldman M. Expression of HLA-A,B,C antigens on primary and 
metastatic tumor cell populations of human carcinomas. Cancer Res 1991;51:6372-80.

46. Restifo NP, Esquivel F, Kawakami Y, Yewdell JW, Mule JJ, Rosenberg SA, et al. Identification of human cancers deficient in antigen processing. J Exp Med 1993;177:265-72.

47. Cen L, Ashe S, Brady WA, Hellstrom I, Hellstron KE, Ledbetter JA, et al. Costimulation of antitumor immunity by the B7 counterreceptor for the T lymphocyte molecules CD28 and CTLA-4. Cell 1992;71:1093-102.

48. Townsend S, Allison JP. Tumor rejection after direct costimulation of CD8 $+\mathrm{T}$ cells by B7-transfected melanoma cells. Science 1993;259:368-70.

49. Sultizeanu D. Immunosuppressive factors in human cancer. Adv Cancer Res 1993;60:247-71.
50. Mizoguchi H, O'Shera JJ, Longo DL, Loeffler CM, McVicar DW, Ochoa AC. Alteration in signal transduction molecules in T lymphocytes from tumor-bearing mice. Science 1992;258:17958.

51. Nakagomi H, Peterson M, Magnusson I, Juhlin C, Matsuda M, Mellstedt $\mathrm{H}$, et al. Decreased expression of the signal-transducing $\zeta$ chains in tumor-infiltrating T-cells and NK cells of patients with colorectal carcinoma. Cancer Res 1993;53:5610-12.

52. Finke JH, Zea AH, Stanley J, Longo DL, Mizoguchi H, Tubbs $\mathrm{RR}$, et al. Loss of T-cell receptor $\zeta$ chain and p56lck in T-cells infiltrating human renal cell carcinomas. Cancer Res 1993;53: 5613-16.

53. Leach DR, Krummel MF, Allison JP. Enhancement of antitumor immunity by CTLA-4 blockade. Science 1996;271:1734-6. 